ISSN: 2238-8052

\title{
GEOGRAPHICAL TRANSITION OF URBAN AREAS. WHEN REGENERATION NOT NECESSARILY MEANS GENTRIFICATION. A CASE STUDY FROM BOLOGNA (ITALY)
}

\author{
TRANSIÇÃO GEOGRÁFICA DE ÁREAS URBANAS. \\ QUANDO A REGENERAÇÃO NÃO NECESSARIAMENTE SIGNIFICA GENTRIFICAÇÃO. UM ESTUDO \\ DE CASO DE BOLONHA (ITÁLIA)
}

Filippo PISTOCCHI ${ }^{1}$

Artigo recebido em 30/04/2019 e aceito em 04/07/2019

Key words:

City centre,

Urban regeneration,

Neighborhood,

Inclusion,

Bolognina.

Palavras-chave:

Centro da cidade, regeneração urbana, bairro,

Inclusão,

Bolognina

\begin{abstract}
A B S T R A C T
Some cities or neighborhoods with a specific socio-economic vocation suffer the phenomenon of change and abandonment, which generates socio-functional and economic redefinitions. This has also happened to the city of Bologna which, over the last 150 years, has experienced a rapid process of economic development, moving from a primary sector economy to a economy based on the industry, to then end up with the most advanced specializations in the tertiary sector. Thus, industries and factories (which had attracted a substantial national workforce) were closed. This has produced the formation of numerous "urban voids», which have turned into abandoned and degraded areas, such as in the Bolognina neighborhood. The consequence was initially the abandonment by the resident population: dwellings remained empty were subsequently occupied by new arrived inhabitants. At first this transition generated contrasts between the pre-existing citizens and the new ones. For this reason, the municipal administration has initiated a series of interventions, aimed on the one hand at the regeneration of the neighborhood in its ethno-socio-economic peculiarities, on the other at the refunctionalization of abandoned areas, to the point of generating a partial process of gentrification. With reference to the territorial Municipality data and according to some published essays and field researches through the Bolognina neighborhood (site inspections and conversation with residents), this article confirms the idea that urban gentrification, urban transition, and urban regeneration are territorial processes in opposition to each other. Each of them can have characteristics and features that are appearently typical of the others, but which, taking shape in a particular territory, are complex geographical phenomena.
\end{abstract}

\section{R E S U M O}

Algumas cidades ou bairros com vocação socioeconômica específica sofrem o fenômeno da mudança e do abandono, gerando redefinições socio-funcionais e econômicas. Isso também aconteceu com a cidade de Bolonha que, nos últimos 150 anos, passou por um rápido processo de desenvolvimento econômico, passando de uma economia do setor primário para uma economia baseada na indústria, para então acabar com as especializações mais avançadas em Bolonha no que diz respeito ao setor terciário. Assim, indústrias e fábricas (que haviam atraído uma substancial força de trabalho nacional) foram fechadas. Isso produziu a formação de numerosos "vazios urbanos", que se transformaram em áreas abandonadas e degradadas, como no bairro de Bolognina. A

\footnotetext{
${ }^{1}$ Adjunct Professor of Political and Economic Geography (BA) and of Geography (MA) at the Department of Modern Languages, Literatures, and Cultures, Alma Mater Studiorum Università di Bologna (Italy) and currently Vice-President of the Emilia-Romagna Regional Board of the Italian Association of Geography Teachers. His main topics are the human and cultural dimension of political geography, cities as territorial phenomena and tourism as a geographical process. In particular, his researches involve West Africa in transition, heritage tourism and cultural itineraries projects, as well as urban policies for the local development. E-mail: filippo.pistocchi@unibo.it.
} 
conseqüência foi inicialmente o abandono pela população residente: as residências que permaneceram vazias foram posteriormente ocupadas por novos moradores. A princípio, essa transição gerou contrastes entre os cidadãos pré-existentes e os novos. Por essa razão, a administração municipal iniciou uma série de intervenções, visando, por um lado, a regeneração do bairro em suas peculiaridades etno-socio-econômicas, por outro, na refuncionalização das áreas abandonadas, a ponto de gerar um processo parcial de gentrificação. Com referência aos dados do Município territorial e de acordo com alguns ensaios publicados e pesquisas de campo através do bairro Bolognina (inspeções e conversas com moradores), este artigo confirma a ideia de que a gentrificação urbana, a transição urbana e a regeneração urbana são processos territoriais em oposição a entre si. Cada um deles pode ter características e características que são aparentemente típicas dos outros, mas que, tomando forma em um determinado território, são fenômenos geográficos complexos.

\section{INTRODUCTION, OBJECTIVES, AND METHODOLOGY}

The city is one of the most complex and at the same time stimulating territorial phenomena. It requires an integrated study by various disciplines and tells of the close link that is created between one or more communities, as well as the space occupied by them and the dynamics that intervene precisely on its territories. Cities, whether they have a long history or are of recent foundations, are constantly experiencing processes of expansion and shrinkage, of transformation and redefinition, due to cultural, economic, political and social changes taking place on both a local and a global scale.

The debate on the city has been lively for many years. I would almost say that it is as old as the city itself. This is because, after all, the city represents the most daring compromise of coexistence between human groups (with their own cultural manifestations), territories (with their climaticenvironmental traits) and the demand to fulfill the needs, projects, and desires of people according to a dynamic equilibrium right among those constitutive elements.

This article wants to be as a sort of open discussion and theoretical/practical reflection on the "city", with reference to the City of Bologna, and in particular to one of its neighborhood, the Bolognina.

Every city is in continuous transformation and adaptation, due to a long list of factors. We usually tend to categorize theese territorial phenomena, with the presumption of reducing them to a monolithic model, which can be reproduced and replicated without distinction. So, urban regeneration of an abandoned and poor area would lead to its gentrification, because new and wealthier inhabitants need new and richer functions; cohabitation in the same territory of different social classes would lead to social contrasts and forms of urban deterioration. Does this always happen? Bologna and its neighborhood Bolognina, even with initial difficulties of integration and social cohesion, are the proof that social and political participation, as well as a sustainable governance, can support urban transformation and transition without forms of exlusion and fragmentation. Transformations is conceived as a tool of improvement, not necessarily as a tool of total gentrification. Data and other 
field researches, as well as site inspections and conversation with residents give the proof of this reflection.

\section{THE CITY, PLACE OF HETEROGENITY}

In another essay (PISTOCCHI, 2018), I played with the semantic duplicity of the term «city», which in the ancient Latin language was indicated by two different terms, urbs and civitas. Urbs meant the material city, made up of full spaces and empty spaces, of houses and streets, prestigious palaces and imposing temples, squares and markets, arenas for games and theaters for the staging of operas and shows; civitas meant the sum of the individuals who constituted it, the citizens united in citizenship, ruled by their laws, moved by a common plan, united by a similar culture. To put it in other words, cities were born to bring people together. To gather in the city meant to divide the tasks and share the products.

Therefore, life in the city22, whether in its entirety or within each of its neighborhoods, implies to make compromises in terms of freedom (individual versus collective) and the relationship between social ties and individualism.

Unfortunately, the uncontrolled growth of the last centuries has upset that original function to the point that, often, the city has paradoxically become synonymous with solitude and isolation.

The multiple challenges facing urban areas - economic, environmental, climatic, social and demographic - are closely interconnected. Therefore, talking about positive urban development requires dealing with an integrated approach that is to combine measures concerning urban material renewal with measures aimed at promoting education, economic development, social inclusion and environmental protection. Collaborations between citizens, civil society, local economy and the different administrative levels is also an indispensable element of this process, and the ability to bring together local skills and know-how is essential to identify shared solutions and achieve sustainable results and up to expectations.

This need has become particularly strong in recent decades, since the phenomenon of globalization seems to have complicated the supposed order that made cities like a system in natural balance. Globalization, in its manifestation, has only accelerated and made more evident the numerous inadequacies that were at the base of common living.

For this reason, one of the global challenges of contemporaneity is to develop an integrated approach to the problem of «urban living», that means possibilities for citizens to live better. This issue ultimately seems to have been subsumed by the terms of sustainable city and smart city, sometimes

\footnotetext{
2 I would prefer to extend the concept of city to every form of stable settlement, even small, to also include all those forms of persistent cohabitation organized on of a territory, more or less endowed with structures and infrastructures, such as for example slums or refugee camps.
} 
over-used to me in recent years. In fact, I fear that sometimes cities are conceived only as projects, without thinking that they are primarily projections into the space of pre-existing cultural, social and political phenomena. This distraction can lead to the mistake of believing that a smart and sustainable model is exclusively a reiteration of the actions, techniques and aspects meant to improve the quality of life of citizens. I would prefer to include a more ambitious goal of livability (WHEELER, 2004) and pleasantness that can sometimes be achieved even by moving away from ideal (aseptic/utopic) plans, which ignore the fact that also citiesas well as natural environments, enjoy an innate resilience condition, and sometimes boasts of a strong, prestigious and long-over-time past. As Castells argues, to manage these urban contradictions requires a vision of the new city (the so called «future city»), without forgetting the historical pattern that underlies the city itself (CASTELLS, 1993).

Kotkin (2005), in turn, claims that cities can thrive only by occupying a «sacred» place that both orders and inspires the complex natures of gathered masses of people. I would like to extend the concept of the sacred by talking more widely about culture, history, society. Terms that all concern the sphere of affections, feelings, and relationships and that manifest themselves, more or less completely, in every urban settlement, even in the most apparently disjointed ones, such as peripheral or central neighborhoods, that have undergone a progressive degeneration or an impoverishment process.

Obviously, the terms «center» and «periphery» carry with them very broad meanings. Often, the periphery is associated with the idea of degradation and exclusion, of poverty and isolation, while the center continues to represent positive images of order, efficiency, and possibility. However, such as Saskia Sassen demonstrated it a few decades ago (SASSEN, 2001), things have changed today, due to the progressive and massive globalization that has involved the entire World. Today, we cannot find a simple straightforward relation between the city center and the core or the CBD, due to many changes that have occurred in particular the new telecommunication systems and the growth of a global economy. In fact, although the CBD remains central to the companies, it is spatially redistributed, even involving peripheral urban areas. This so-called «economic viability» is at the base of a wider social and cultural mobility that takes shape precisely within the contemporary city, where the center and the periphery, even with evident contrasts, share and live the same similar urban experience.

This theory is confirmed by the words of Matilde Callari Galli, who states with a certainly fascinating narration (CALLARI GALLI, 2008) that the historic center of Bologna still maintains its ancient function as a place of exchange: not exclusively commercial and material exchanges, but also immaterial, cultural and symbolic. It is precisely from this functional and socio-cultural mix that a coexistence and a sharing of spaces by extremely different social groups is manifested: common citizens, rich bourgeoisie, students, traders, service workers, immigrants, etc. This socio-cultural mix is favored by a spatial continuity, made possible by both the small size of the historic center and a particular architectural structure that for centuries has characterized the territorial grid of the city: 
the porticos, 43 chilometers long. Therefore, people (both citizens and city users) live (and live together) under the same architecture. Although there is a natural spatial demarcation between the most popular areas and the richest ones, an evident fluidity characterizes the urban fabric of the city. The legitimate (formal) society and the illegitimate (informal) society cohabit, meet, clash (because they are not concretely amalgamated and manifest needs, attitudes, and practices sometimes dissonant with respect to the needs of others), but they also mutually support each other, since, after all, one group needs the presence of the other. Given this spatial uniformity that favors a certain socioeconomic complexity, it is therefore possible to consider in some respects the historical center as made up by the socio-economic center and the socio-economic periphery. Similarly, the suburbs and less central neighborhoods can be considered as as influenced by the historical center of the city, with its needs, its functions and its activities.

\section{THE CITY, SPACE OF COMPLEXITY: DEMOGRAPHIC DYNAMICS AND URBAN DIVERSITY}

The city is a place where productive and market activities, services, places of worship and decision-making bodies are concentrated and developed. It is within the city that organizational decisions and changes in the territory are processed.

The city, however, is more than this funcional system: it is a complex organism with its culture, its values, its institutions and social relations. The city consequently constitutes a geographic phenomenon of particular interest, due to its «trans-urban» dimension (SASSEN, 2008) and, I would add, sub-urban, on which trans-border and extra-border territorial processes are realized and determined. This confirms that the geographical space of the city does not correspond to that of the urbs: the magnetism of the city enters widely into its suburbs, which in turn are projected into a larger spatial dimension ${ }^{3}$ than the city itself.

The city is also the result of continuous demographic dynamics. In fact, migration flows are transforming force of societies on the socio-political, economic, cultural levels. Speaking of migrations and cities is proper to geography, from the economic to the urban, from the political to the cultural aspect (PISTOCCHI, 2017): whether it is a small settlement or a metropolis, immigrants have been attracted by one city, probably because they presumed that it could satisfy their needs; at the same time, the presence of new immigrant citizens (of different cultures) exerts a transformative action on the city, speeding up its natural process of adaptation to the times and needs of its existing citizens. Therefore, we should analyze urban settlements and human mobility as important geographical factors, constantly changing, both as regards the morphology of the territory, both as regards its landscape, and, ultimately, the numerous cultures that are there manifested.

\footnotetext{
${ }^{3}$ Soja (2007, p. 290) described this phenomenon using the term «exopolis».
} 
Also due to the above mentioned phenomena, in contemporary cities there are growing intellectual occupations, but also workers who provide non-specialized services, i.e. the lower strata of the social structure (SCROFANI, RUGGIERO, 2012). The new urbanization trends have brought significant changes with respect to the shape, density and spatial dimension of cities, making the boundaries increasingly blurred, dilated and invasive of the surrounding countryside. This has given rise to different urban forms, given by different demographic, economic, political and social situations depending on the place where the urbanization occurs.

Big cities, in particular the metropolis, stand out from the other settlements due to their multiple ethnic composition. Today, this characteristic has often been strengthened but also extended to smaller cities, above all because, in proportion to their size, they have been the main destinations of large international migratory flows since the last century. In the Fifties and Sixties of the last century and even more in the phase of decolonization, masses of African and Asian migrants settled in the cities of the former colonial countries, especially in Great Britain, France and the Netherlands. Since the end of the Twentieth century, international migration has steadily increased and affected practically every part of the world. The main migratory flows generally go from the poorest and underdeveloped areas (Africa, Latin America and Asia) to the most developed ones (Europe, USA, Canada, Middle East, East Asia, Australia). This has produced, in many destination cities, a more ethnic than social stratification, even if the two characteristics, given the very low incomes of migrant populations, often end up coinciding. In Italy the arrival of migrants has caused a certain impatience from the cultural point of view, with respect to habits, ways of life and different attitudes. These attitudes are particularly evident in the cities with the greatest number of immigrants and illegal immigrants in particular (CRISTALDI, 2013; DEMATTEIS, LANZA, 2014).

Marginality and peripherality are two conditions that are predominant in many urban scenarios, generally in the larger, open, and globalized ones. Often, they are located in some neighborhoods that, although spatially central, are not particularly included in the urban dynamics of the city, and this happens for reasons of historical, economic, ethnic nature.

\section{URBAN SPACES, ETHINC LANDSCAPES}

The urban space is varied in its interior. In the urban fabric you can find neighborhoods inhabited by homogeneous social classes, formed by buildings of a single type and specialized in a single function, or multi-purpose neighborhoods, that are mixed, inhabited by different social classes, in which different functions and activities take place (CRISTALDI, 2013).

Referring to the so called «emotional geography» (of territories), deeply studied in recent decades "the 'feel' of a place is made up of experiences, mostly fleeting and undramatic, repeated day 
after day and over the span of years. It is a unique blend of sights, sounds, and smells, a unique harmony of natural and artificial rhythms registered in one's muscles and bones" (TUAN, 1977); moreover, "places exert a powerful influence on people's feelings and knowledge productions, while people exert a powerful influence on and within place" (BARTOS, 2013).

The signs of different cultures, with their symbols, colors and smells, give essence to new landscapes, whose even the indigenous people, the signs in foreign languages, and the aromas of unknown spices are an integral part.

The progressive transformation of the places characterized by a very high density of ethnic signs, makes now visible the rooting of the foreign community in a space where the old and the new community live and perceive, understand, and interpret that urban landscape.

The residential spaces, the spaces linked to the movement, the spaces dedicated to religious practice, those dedicated to commerce are all «tangible» and visible tools that create the urban image as a whole.

We must not forget, however, also the «intangible» tools that characterize the urban diversities and the uniqueness of a city: the spread of different languages, both oral or written on advertising signs, the somatic traits of its inhabitants, the complex of symbolism used for ornaments and decorations, the variety of foods, clothes, objects that not only satisfy the physiological needs of the buyers, but that contribute to strengthening the sense of ethnic identity and the link with the homeland.

As Cristaldi wrote (2013, p. 83), the ethnic landscape represents the visible manifestation of cultural diversity in the territories of everyday life and is related to the perception of the immigration phenomenon in its territorial dimensions.

Commercial activities are a very frequent occupation for foreigners and the formation of real specializations of the different national groups in the commerce sector is common. In the urban fabric the signs of ethnic commerce are numerous.

In Italy, for example, ethnic shops often take over the ceased activities of Italians. Frequently they do not guarantee a merchandise continuity, therefore initially the commercial activities are intraethnic, that is, they attract individuals belonging to the same community of origin. With time they will become inter-ethnic, also addressed to other populations, such as the local one who were initially excluded.

Some activities, such as call center shops, however, are hardly used by local communities.

Even the small grocery stores, which sell products unrelated to the food and wine traditions of the receiving country, are aimed primarily at some communities. Normally, it is the way of exhibiting the products, the language used, the type of products themselves that indicate whether that business is mainly aimed at the members of the community or not. 
The signs of identity, in fact, diminish when the trade is addressed both to foreign and local communities. Among the various commercial activities, bars and restaurants represent not only sales places, but meeting places, because after a transition and adaptation period, the members of an ethnic community are increasingly looking for meeting spaces and socio-cultural communion. The presence of ethnic commercial activities does not always find acceptance within urban neighborhoods, sometimes on the part of citizens, sometimes on the part of local administrations themselves, which intervene with specific regulations.

Even the presence of places of worship represents a form of stabilization of the foreign community in the area, and indicates its effective presence. This phenomenon can be harbinger of divisions and hostility.

\section{URBAN DIVERSITY, DECENTRALIZATION AND ETHNIC SEGREGATION}

When we talk about segregation, we often think of violent and manifest forms of sharp separation between territories and communities, as a result of bad political actions and of wicked administrative choices. This condition of segregation, however, can also originate «naturally» and «historically», from forms of territorial discontinuity (FRÉMONT, 2007), which interrupt the social space and therefore make cohabitation, exchange, and sharing more difficult.

Obviously, a number of factors are involved in this process: economic (wealth vs poverty), real estate (luxury housing vs social housing), cultural (high school attendance rate vs linguistic illiteracy).

As mentioned above, ethnic minorities within the city tend to self-segregate by concentrating themselves in the same neighborhood, with the aim of supporting and helping each other. This causes an uneven spatial distribution with respect to the rest of the urban population. Usually, newcomers tend to settle in «marginal» areas of the city, even spatially central, but «peripheral» in respect to their social and economic influence.

As a result, the refusal of the «different» and the racial prejudice can be quite evident phenomena.

These facts have concrete and clearly visible consequences, in particular the real estate devaluation, actions of hostility or even the abandonment of that area by previous local residents: newcomers are considered as competitors in the division of resources, or worse, generators of poverty (DEMATTEIS, LANZA, 2014).

Undoubtedly, on the general level, ethnic segregation is conditioned by the national policies of each host country. Policies vary from the extreme of a forced assimilation - which tends to minimize the diversity between immigrants and local populations, even through coercive means - to the 
opposite extreme of multiculturalism - which leaves freedom of expression to cultural diversity, as long as it is not contrary to the laws in force.

In the Twenties of the last century, in the urban areas of the North America there was a rapid demographic growth, due to the massive flow of immigrants from Eastern and Southern Europe, enticed by the strong industrial development. In this context, the Chicago School scholars focused precisely on the multi-ethnic reality that characterized the cities. Segregation was to be considered as a temporary phenomenon. According to their theory (the theory of assimilation), immigrants in the host country occupy a space in which migrants from the same community of origin are already present. When, subsequently, they fit into the linguistic and working context, they move from these degraded areas (ethnic niches), to less disadvantaged urban areas, thus distributing themselves into «multi-ethnic» urban spaces. Therefore, they free up some spaces, which are again occupied by other low-income populations.

This model was taken as a reference in the US and Canadian context, but was less exhaustive applied to the European urban context, characterized by urbanization processes of much longer duration and very different territorial policies depending on the State. Moreover, that theory does not seem to consider those forms of ethnic discrimination that have proved to be persistent over time, preventing the mobility of these groups within urban neighborhoods.

The process of urban decentralization began to appear starting from the second half of the Twentieth century, mainly for two reasons: to rebuild what was destroyed due to WWII and to create new housing areas able to meet the needs of the immigrant flows. The objective was an urban development that favored economic growth, strengthening industrial and artisanal areas and guaranteeing services to the population. In the following decades, this process of decentralization continued, so much so that the need to provide the various urban areas with administrative autonomy, services, schools, transport but also a sense of community emerged. Thus, with the logic of a «reformist urban planning» to favor the qualitative development of the urban fabric, in the 1960s, Bologna was the first Italian city to introduce neighborhood councils in the popular areas that were adjacent to the historic center, immediately outside the walls, just behind the train station.

That socio-economic experience has been in downfall since the 1990s with the industrial crisis, and with the arrival of massive migratory flows. It has not even spared Bolognina.

\section{BOLOGNINA: FROM AND ITALIAN WORKING-CLASS TO A MULTI-ETHNIC NEIGHBORHOOD}

In Bologna, the territorial distribution of immigrants has profoundly changed over time: until the 2000s the areas with the highest incidence of foreigners were mainly the districts of the historic center, while in the last two decades it was the peripheral areas that registered the most 
significant presences. The center of gravity of the location of foreigners has tended to shift from the areas to the south (Saragozza, Santo Stefano), residential areas characterized by higher building quality and green areas, to the more popular areas north of the city (San Donato, Navile, Reno), marked by the lower cost of living and by the presence of many housing blocks, where housing costs tend to be lower (Figure 1a, 1b).

Figure 1a. Neighborhood 1962-1966

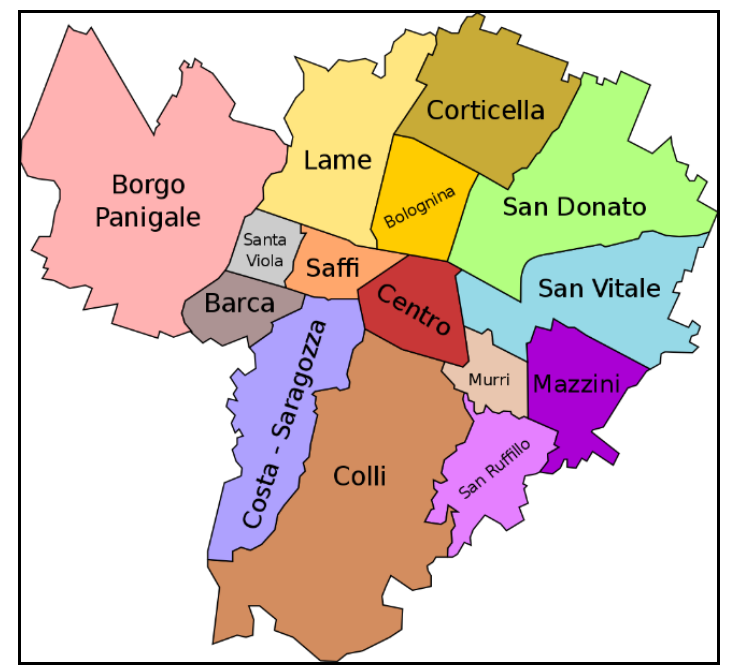

Figure 1b. Neighborhood today

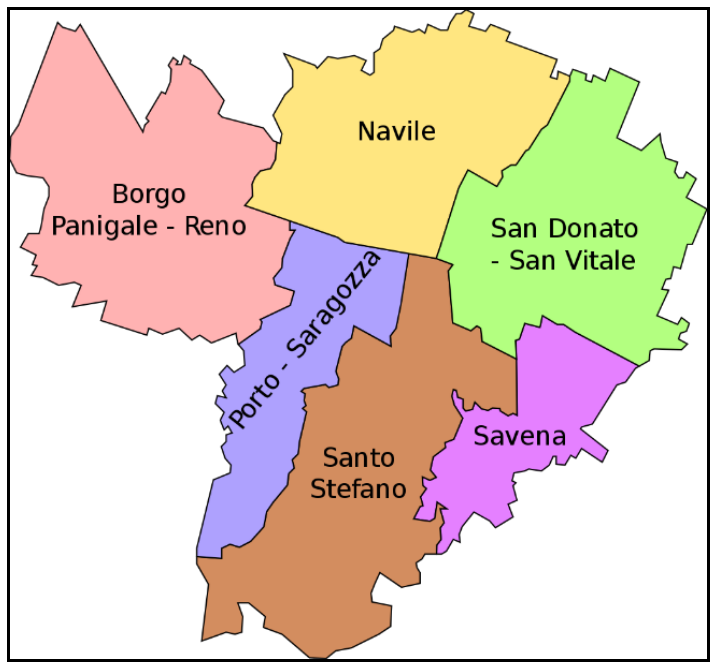

Figure 2a. Italian inhabitants in Bolognina (1985-2015)

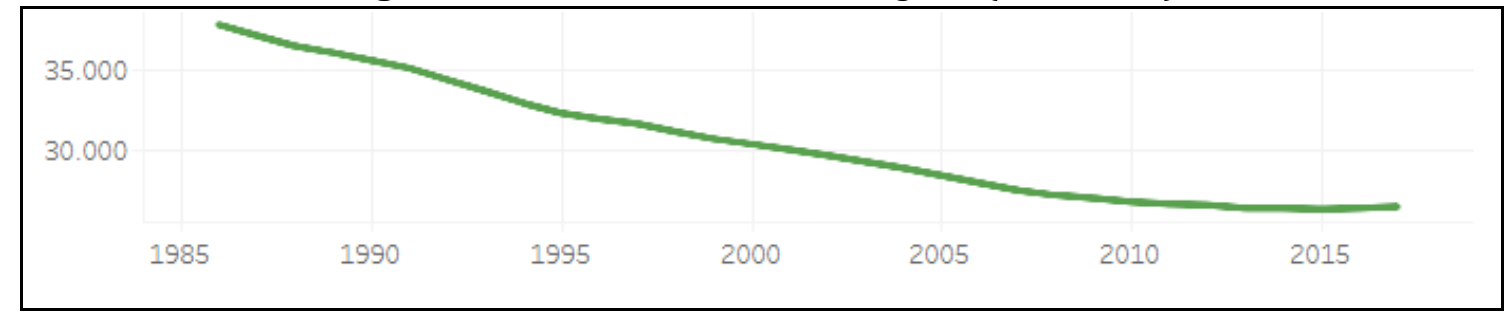

Figure 2b. Foreign inhabitants in Bolognina (1985-2015)

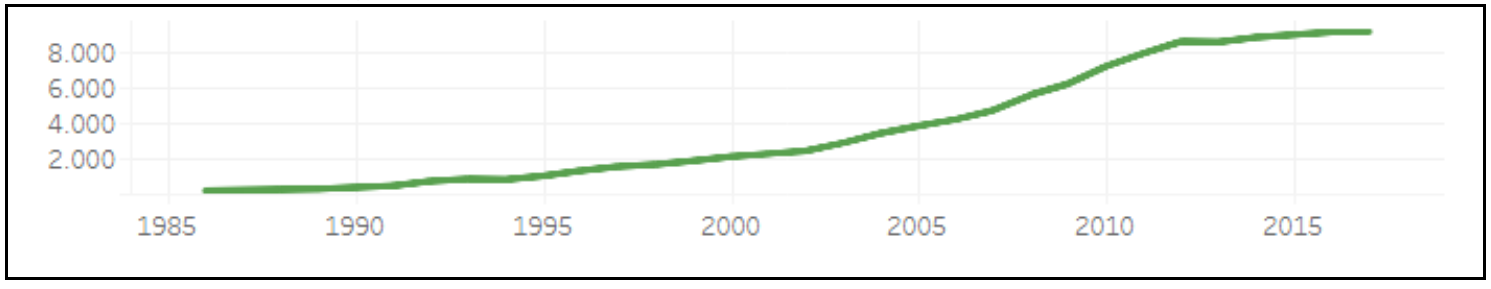

According to the Statistics Bureau of Bologna ${ }^{4}$, the incidence of foreigners on the total number of residents in the municipal area of Bologna follows a positive trend that since 2000 has more than tripled the percentage. In 2017, 15\% of foreigners residing in Bologna are in the Bolognina area, a number that represents $26 \%$ of the total population of the area.

${ }^{4}$ http://statistica.comune.bologna.it/quartieri/cittadinanza; http://inumeridibolognametropolitana.it/datistatistici/popolazione-residente-straniera-quartiere-zona-e-cittadinanza-dati-mensili 
Even in Bolognina, in line with the regional and provincial trend, migratory flows have counterbalanced the tendency to aging and to decrease of the local population. The latter has steadily decreased compared to that of foreign residents, who on the contrary is constantly increasing (Figure $2 \mathrm{a}, 2 \mathrm{~b})$. The percentages of the various national groups both in the municipal territorial area and in the Bolognina area tend to be homogeneous, even with a clear concentration of the Chinese community precisely in Bolognina.

Although foreigners are more concentrated in some neighborhoods and are therefore not evenly distributed in urban space, in Bologna there are no particularly marked forms of urban segregation, let alone real ethnic ghettos. Thus, Bolognina is not a ghetto, even if the resident foreign populations have suffered the most from the labor market crisis of the last decades and have been partly relegated to the margins of the services economy, with very low and scarce wages work protections.

Bolognina is today a popular neighborhood in transition (BATTISTINI, 2018). This district extends in the area north of the historic center of Bologna, in an area bordered to the south by the Central Station, the Navile Canal to the west, the Bypass to the north and east by via Stalingrado (Figure 3).

Figure 3. Author's elaboration from Google Maps View of Bologna, with the Bolognina neighborhood right on the northern side, just behind the Train Station.

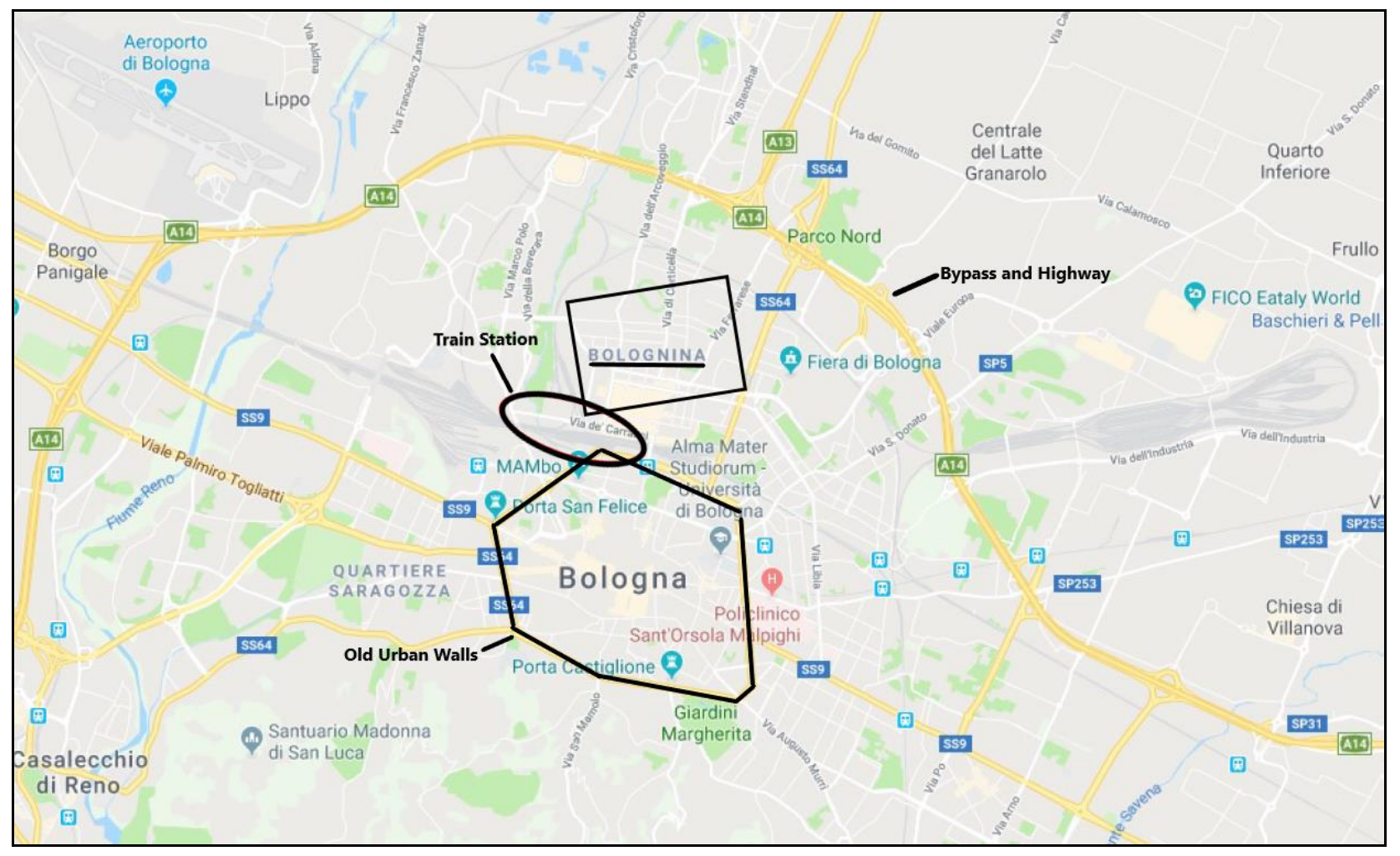


As stated by Ruocco (2012), Bolognina is a particularly significant example both of the demographic and economic-productive mutation processes and of the urban redevelopment projects started in the last years.

Its history dates back to the late Nineteenth century, when it developed as a working-class neighborhood; today it struggles with industrial decommissioning and with many empty/abandoned spaces. Its inhabitants feel threatened by the crumbling of their model of community life and welfare that has made its way with the arrival of new foreign populations that have arrived in this area. It is the most multi-ethnic neighborhood of the city and at the same time also the manifestation of a complex mosaic of social stratifications: a heterogeneous cross-section of age, origin, social class, income. In this portion of the urban fabric old inhabitants and new immigrant populations come close to each other, ignore each other, and share the same places.

With the industrialization of the end of the 1800s, Bologna underwent an important territorial expansion beyond the walls. The construction of the Central Station (work began in 1858 and lasted 6 years, but in 1859 some railway sections were in operation) marked a fundamental stage for the development of the northern suburbs of the city. Thanks to its strategic position, which made it the main railway hub for communications from the north to the country, Bologna gradually assumed an increasingly important role from a commercial point of view.

With the Regulatory and Enlargement Plan of 1889, which provided for urban expansion to the north just behind the Station, and after the demolition of the city walls, numerous industries arose as early as the early 1900s. Around them the urban fabric was modeled to respond to the housing needs of the workers, giving life to a neighborhood that recognizes a strong working class identity. Identity that was strengthened during the Fascist period, when the factories and the entire neighborhood became a place of dissemination and organization of the anti-fascist struggle.

\section{THE SOCIO-ECONOMIC VARIETY OF BOLOGNINA}

In the second post-war period, social cohesion, solidarity and a sense of belonging to the community continued to maintain strong relations between members of the neighborhood community, in particular strengthened by wage struggles for the rights of workers linked to factories. Starting from the 1980s this productive and social model went into crisis, until it broke completely, following the closure of numerous industrial activities (PIANO B, 2007).

Thus, the traditional community structures of the workers' sociality of the neighborhood were weakened (SCANDURRA 2015). 


\subsection{THE CHINESE AND THE REVITALIZATION OF A DECLINING NEIGHBORHOOD}

From the mid-twentieth century, the first Chinese immigrants began to arrive to Bologna, settling in the central areas of the city, and dedicating themselves mainly to small textile, leather goods and catering activities. Other massive waves of migratory flows from China occurred since 1985, after the fall of the Maoist regime, and from 1995 onwards, coinciding with the rapid economic boom of the motherland and with the consequent formation of a strong gap between rich and poor.

The settlement of the Chinese population in Bolognina coincided with the decline of the industrial production model and the consequent disposal and closure of several historic factories in the neighborhood. In those years the Chinese community was looking for spaces for textile laboratories and leather goods or for commercial activities of various kinds. Thus the Chinese community actively settled in a neighborhood that was gradually being emptied. Over time, even the economic activities of the Chinese population have undergone non-secondary changes. Chinese entrepreneurs have abandoned local production, where production costs and standards are higher, and have found it more convenient to deliver goods directly from China. Thus, the spaces previously used as laboratories have turned into wholesale or retail outlets: clothing stores, bars, health food stores, grocery stores, restaurants, travel agencies (Figure 4).

The Chinese community is not very interested in a complete socio-cultural integration with the other groups, including the group of Italian residents and this attitude has in some cases generated discontent in other citizens, in a neighborhood that, until a few years ago, would have had a great need to rediscover a propulsive factor for cohesion and the «social rebirth».

Figure 4. Business shops held by the Chinese community in Bolognina (google.maps).

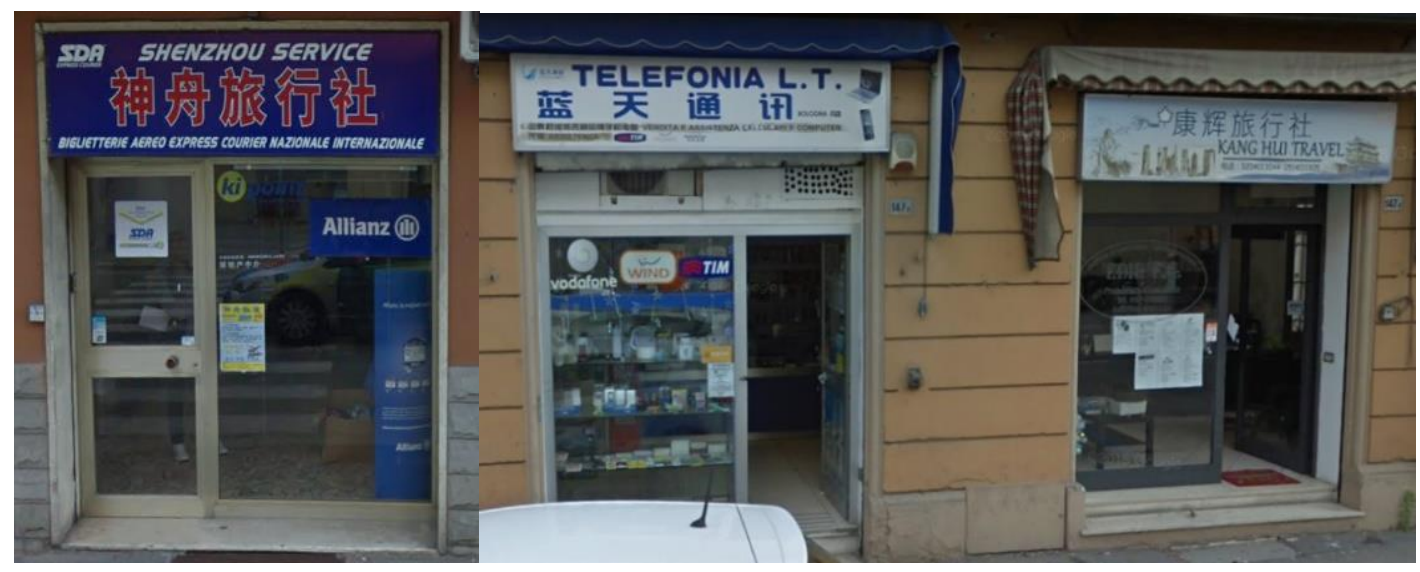




\subsection{THE VIA ALBANI MARKET}

Not far from the Bolognese China Town, in 1934 the Albani Market ${ }^{5}$ was born, following the construction of the first popular housing residences. It is a semi-covered structure divided into boxes, adjacent to each other, arranged in two mirror rows and divided by a wide corridor (Figure 5).

The commercial activities belong to various product sectors. There are butchers, fruit and vegetable shops, clothing, tailoring, fishmongers and bars. Both for the relationships that are established between the merchants themselves, and for the relationship that exists between merchants and customers, this reality can be read as a social cross-section that spatially reflects wider dynamics of the Bolognina neighborhood. The heterogeneity of the traders' nationalities also joins the heterogeneity of the present activities.

The type of customers, on the other hand, is generally more homogeneous, made up of middleaged or elderly people, habitual residents of the area. On the market there are greengrocers of different origins but they all sell more or less the same products, with the will to turn to a local customers. In interethnic commercial activities, identifying signs, such as language or product types, are less present. From the observations of the interaction between foreign traders and local customers, a degree of confidence and harmony is not obvious, given the general climate of distrust towards foreigners by local populations. Within the market, spatial proximity and cultural sharing among merchants favors the establishment of personal relationships, as well as collaboration and support in the work.

Figure 5. Via Albani Market.

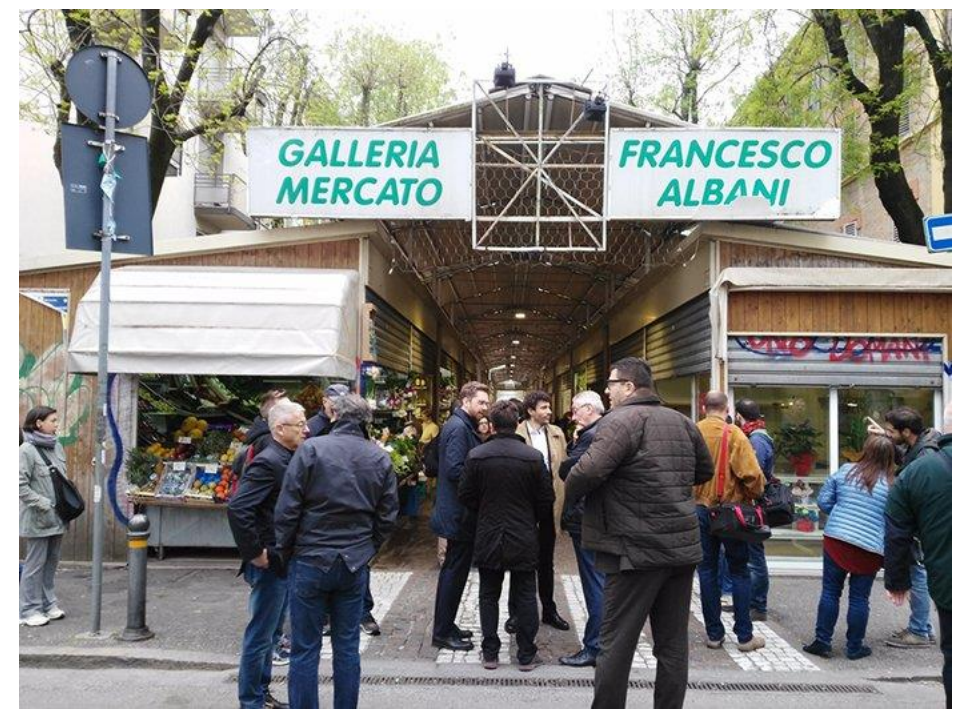

Source: http://www.dire.it/04-04-2018/189329-a-bologna-musica-e-tavolini-al-mercato-di-via-albani-arrivalok-dal-comune/

\footnotetext{
${ }^{5}$ Spadea, https://www.academia.edu/26416205/Etnografia_di_un_mercato_storico.
} 


\subsection{THE ISLAMIC BUTCHER SHOPS}

Islamic butcher shops (Figure 6) are mainly run by Moroccans and Egyptians. The former dedicate themselves to this type of activity as an alternative to subordinate work by workers, while the latter already possess a cultural background in this profession, in many cases familiar. The general tendency is to detect premises already used as butcher shops, so as to save on the accessories and specific tools necessary for this activity.

These shops are open every day: generally, there is never a single person to manage the activity, to allow to keep the shop open even during the time of prayer that is recited in the back. The customer of hahal butchers is mainly foreign (Islamic). There are few Italians, especially students, young and southerners who do not buy meat, but other types of products, at low prices, such as cheese, dried fruit, fermented milk, prayer rugs, teapots, packaged products. Unlike the most common minimarkets managed by immigrants, generally Pakistani and Bengali, in halal butchers do not sell pork or alcohol. These butchers are strategic points of aggregation for Muslims. The search for halal meat does not only refer to a religious significance but is above all a cultural experience and this means that Islamic buyers come here even from other areas of the city, also attracted by the excellent value for money and the value of trust compared to every single activity.

The Bolognina represents therefore a supply channel recognized by the Arab community and not only.

Figure 6. Islamic Butcher's

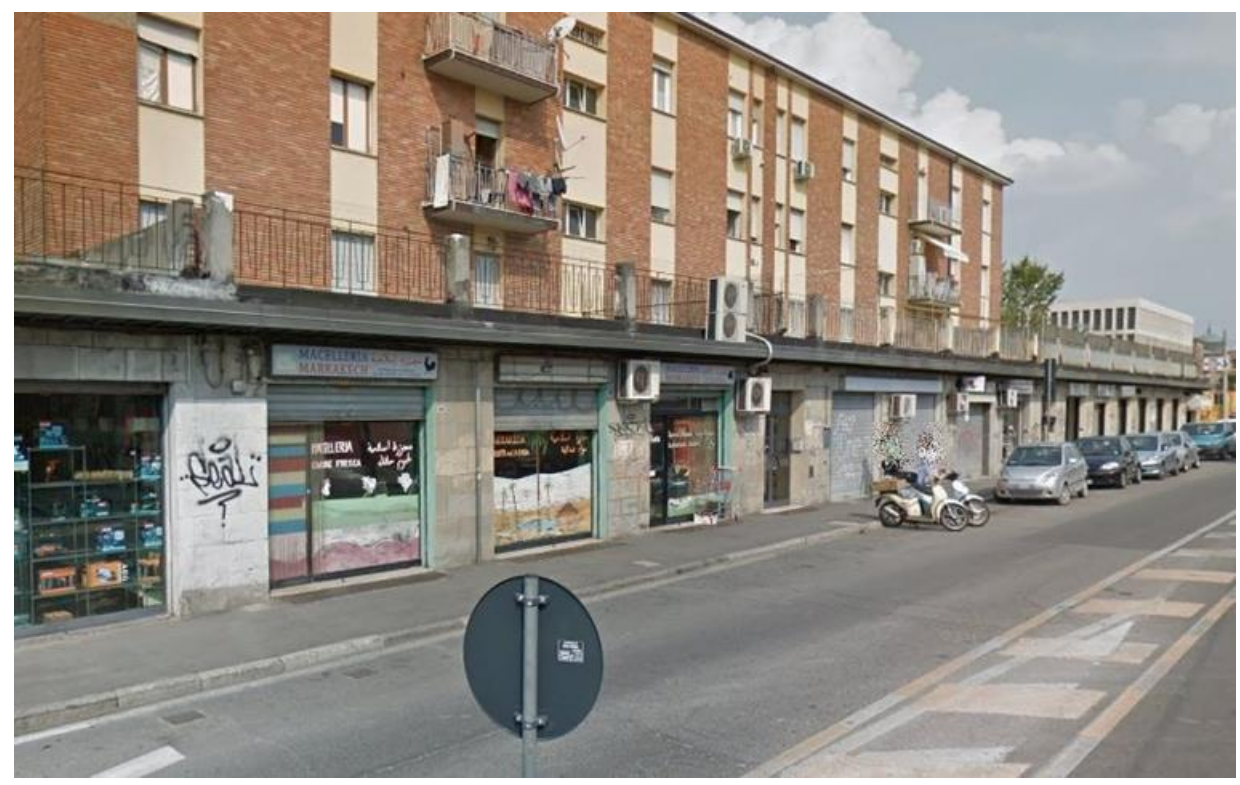

Source: èTV Rete7. 


\section{BOLOGNINA: REGENERATION OF ABANDONED AREAS, THE ROLE OF ETHNIC DIVERSITY, AND URBAN LANDSCAPE}

As previously mentioned, the decline of the industrial production model, the closure of the large factories in the neighborhood, and the arrival of large flows of foreigners, have had a negative impact on the strong identification and sense of territorial belonging of the old inhabitants of the area. The abandoned areas in a state of semi-abandonment, have become the symbols of a widespread degradation in the collective imagination. These abandoned areas have contributed to generating and nurturing a sense of loss, abandonment and of social and cultural «disorientation» (BATTISTINI, 2018).

With the dismantling of the factories, a symbol of the neighborhood, the identity of the area was also shattered (TANCREDI, 2005).

Enormous spaces stand like desecrated cathedrals to shape the landscape of this area. Thousands of square meters occupied by crumbling structures, inhabited by mice, weeds and homeless immigrants. The places that symbolize society and workers' struggles for a long time have become the spaces of social exclusion.

Following the economic crisis and the decline of the industrial model, and in conjunction with the arrival of foreign populations, a sense of disorientation has spread among the populations, which has then turned into increasingly widespread forms of intolerance.

Citizens complain about the lack of cleanliness of some areas, not sufficiently taken care of, also because of the habits of some citizens and traders or of people bivouacking in the street. They complain of poor lighting in some areas, illegal trafic, theft, and vandalism. These aspects generate a growing sense of insecurity, but among the elements that most influence discomfort is the lack of integration and knowledge with the new foreign citizens in the area. Discomfort is accompanied by a sense of loss of one's community identity, a sense of belonging that was characteristic of this area in the past. The attitude of those who lived the years of Bolognina worker is that of a nostalgic look at the past and a severe judgment towards the present, which turns into real forms of cultural impatience.

To cope with these difficulties, many of the realities presented here in recent years have been involved in recovery and regeneration projects. As Marcello Capucci wrote (2014), the neighborhoods must be «regenerated» rather than «redeveloped»: not only because the second term basically refers to the idea of a change of state, that is to say from a bad situation to a good one; but also because a positive transformation must be achieved throught a process, starting from what there is to work on it, to reinvent it, to adapt it to different and changed needs, in a logic of valorisation of a fabric that has its rules, on which it was built and thanks to which it was able to define its own recognisability. 
The projects carried out, in progress or under study are numerous and aim at the realization of various works, from social housing, to housing redevelopment, to new public spaces, green spaces, schools and student housing. Some of these have tried to regenerate the area involved, saving their pre-existing identity. Others, on the other hand, have proposed a radical renewal, which has brought with it forms of reconversion and refunctionalization: for example, the former Officine Minganti, a famous abandoned metalworking factory that since 2006 has host a shopping center. Despite the intention of the project to keep the historical memory of the place and consequently also of the neighborhood alive in its structural features, the inhabitants' lack of social mirroring is clear, in an area characterized by the strong presence of immigrants of Chinese origin. This recovery operation suggests an attempt to address and attract a wealthier clientele, such as to guarantee a process of gentrification. That of the Minganti workshops, however, is a story of failure, which led to their closure after only 10 years of their inauguration. Probably, the lack of integration with the social fabric of the neighborhood did not favor its development.

In other cases, the «bottom-up» transformation of various commercial realities has yielded better results. "In this part of the city, the urban regeneration projects and the transformation of the commercial landscape are encouraging the introduction of reinvestment mechanisms, following a long period of commercial and residential disinvestment. The recent development of the new businesses coincided with the gradual arrival of new residents and contributed to create a commercial space differentiated in terms of type of customers and localization of concerns. The new businesses also seem to follow a direction of development that can be related to the advance of gentrification and the residential location of gentrifiers" (BAZZOLI, 2016, p. 10).

The two prevailing trends observed in this neighborhood are an expansion of foreign-owned trade and an increase in the quality level of the commercial offer. In the last decade gastronomy of typical products, restaurants and points of sale of organic foods, vintage shops, vegetarian or vegan restaurants are proliferating. Such types of consumption refer to the lifestyles of the new middle class. This suggests a direct correlation between the arrival of the middle class and the flourishing of new commercial and commodity categories that are to be considered a sign of the presence of consumption patterns related to it. Often, these activities take over from previous commercial realities, of which they do not guarantee a merchandise continuity, sometimes, instead, they arise in new spaces obtained following the conversion of the building heritage. In particular, the expansion of ethnic, biological and quality catering is influenced by the appreciation of cosmopolitan and sought-after culinary consumption of this social class. Compared to the historical inhabitants of the neighborhood, this social category shows a tendency to food consumption outside the home. They are mainly young and single, or couples without children, or, if with children, they are professionals with a double career. The relationship between the lifestyles of these new inhabitants and the district's commercial 
offer is actually two-way. If it is true that these relate to the renewed commercial offer of the area it is equally true that it is influenced by it in adapting to their rhythms of life. The old inhabitants of the districts and the immigrant populations, on the other hand, favor the consumption of domestic meals. When they go to the restaurants, their choices are oriented towards historical and traditional activities. Indeed, the new gentrified class seems to prefer ethnic restaurants, places that represent the only opportunity for meeting and contact between these two social and economic categories.

Right inside this complex and new neighborhood community is the successful regeneration project of the Albani Market.

This local market, which since 2015 obtained the qualification of «Historic Market», has been the subject of a regeneration and enhancement project, with the aim of becoming one of the relaunching poles of the entire Bolognina. The intervention involved several sectors. The Municipality has commissioned to Confcommercio and Confesercenti Emilia-Romagna an analysis to highlight the critical points in order to define the necessary interventions. The new LED lighting has been realized under the roof, which covers the whole street of the market. Video surveillance cameras inside the market and an additional camera were installed at the entrance. The regeneration of the area also saw the removal of the disused public bathroom and the renewal of the ecological island for waste collection, located at the entrance. New parking lots have been created, and the bike parking racks have been restored and expanded, as well as the sidewalks nearby. The project was the prerequisite for the market enhancement plan, effective from February 22, 2016, with which it was given the opportunity to open other commercial activities in addition to food ones.

The shutters of the market benches, the external walls of the structure and also the small squares all around were decorated by young artists, according to the street art models. This was possible because the idea behind the whole project is that an aesthetically more beautiful market embellishes the entire neighborhood; and so, the Municipality has allocated funds for the construction of flower beds ${ }^{6}$.

The urban, economic and cultural changes that have involved and involve Bolognina also change her landscapes. Gentrification, in this sense, possesses a series of visibly perceptible elements, through the redefinition of urban spaces.

Certainly the spaces symbolizing the workers' past of the neighborhood are among the most visible symbols of this ongoing process, since in them continue to live different urban groups, close but separate, together but individually.

This variegated mosaic of the urban landscape of the neighborhood, which also combines new architectural elements with old elements, is the most obvious symbol of this area's change. Walking through Bolognina, what is most striking is its fragmentation: the contrast between historical

\footnotetext{
${ }^{6}$ http://www.comune.bologna.it/news/mercato-albani-la-bolognina-che-cammina.
} 
buildings of the neighborhood and new architectures are, together with the various commercial activities, one of the aspects that strengthens the visibility of gentrification, in contrast with a more humble reality, made both by elderly Italian residents and by new generations of immigrants (BAZZOLI, 2016).

The population's relationship with the spatial changes in this area also seems to be mixed.

For historical residents, the new building types cause a sense of strangeness, a striking sensation with the typical physical characteristics of the neighborhood. Also some categories of new inhabitants of the area, such as students, perceive in a negative way this lack of continuity with the pre-existing spatial conformation, which they considered the fulcrum of the popular identity and the attraction authenticity of the neighborhood. For most of the new gentrification populations of the area, however, the contrast between architectures is to be considered the symbol of a new development of the neighborhood, of which they are considered an integral part.

\section{CONCLUSIONS}

The urban, economic and cultural turns that have transformed and still occur to Bolognina also contribute to change its landscapes. Gentrification, in this sense, has a series of visible and perceptible elements, through the redefinition of urban spaces.

Certainly the spaces symbolizing the workers' past of the neighborhood are among the most visible symbols of this ongoing process, since in them continue to live different urban groups, very close but separate, together but individually,

This variegated mosaic of the urban landscape of neighborhoods, which also combines new architectural elements with old elements, is the most obvious symbol of this area's change. Walking through Bolognina, what is most striking is its fragmentation: together with the various commercial activities, the contrast between historical buildings and new architectures are one of the aspects that strengthens the visibility of gentrification, in contrast with a more humble reality, made both by elderly Italian residents and by new generations of immigrants.

The population's relationship with the spatial changes in this area also seems to be mixed.

For historical residents, the new building types cause a sense of strangeness, a striking sensation with the typical physical characteristics of the neighborhood. Also some categories of new inhabitants of the area, such as students, perceive in a negative way this lack of continuity with the pre-existing spatial conformation, which they considered the fulcrum of the popular identity and the attraction «authenticity» of the neighborhood. For most of the new gentrification populations of the area, however, the contrast between architectures is to be considered the symbol of a new development of the neighborhood, of which they are considered an integral part. 
The phenomena that contribute to forming the landscapes of our cities are complex and see many factors and actors involved.

In the first case, the fact that Bolognina is located on the edge of the historic center, initially inhabited by Italian citizens belonging to the lower socio-economic working-class and only later by foreign immigrant populations, who sometimes replaced the previous community.

In the second case, the Administration's interest in attracting capital and human resources, ie the new middle class, which translates into urban planning policies for large-scale redevelopment and renewal.

These interventions, consciously or unconsciously, favor the so-called gentrification, aiming at an elevation of the economic and social structure primarily of the area concerned.

This also happened to Bolognina, where a process of gentrification certainly took place, which, however, has not affected the pre-existing social structure.

What is noticed is a sort of splitting of the urban reality that is realized in different ways: 1) splitting of lifestyles and consumption that sees, on the one hand, the historical inhabitants of these neighborhoods and the foreign populations and, from the another, the new gentrificating middle class; 2) spatial splitting which is given by the non-homogeneous distribution of new commercial activities and of the new social class.

The tendency of the new social class to concentrate in the most central areas and close to the historical center of the city is quite evident and this aspect contributes to strengthening the visibility of the gentrificatory process. In this sense, it seems that in the neighborhood two different ways of living coexist, which more or less clearly do not usually mix, but rather ignore each other.

Gentrification manifests itself in material space, but also in the story and in the representations it generates. The combined effect of the material transformation and the narration of this process contribute to accentuating its visibility.

However, delineating the characteristics of a complex phenomenon such as urban regeneration and gentrification in its evolutionary phase is an open-process.

\section{REFERÊNCIAS}

BARTOS A. E., “Children sensing place”, in Emotion, Space and Society, 9, 2013, p. 89

BATTISTINI S., Urbanizzazione e gentrificazione. Casi di studio a confronto: la Bolognina a Bologna e Saint Michel a Bordeaux, Tesi magistrale in Lingua e culture italiane per stranieri, Università di Bologna, a.a. 2017/2018

BAZZOLI N., La Gentrification nelle Città di Media Dimensione: Cambiamenti Socio Spaziali in Prospettiva Comparata. Un Confronto tra Bologna e Bristol, Corso di Dottorato di Ricerca Dipartimento Economia, Società, Diritto, Università degli Studi di Urbino Carlo Bo, a.a 2015/2016

BERGAMASCHI M., "Interstizi urbani: la distribuzione residenziale degli stranieri a Bologna", in A.A.V.V., Agenti metropolitani. Progetti per Bologna, Editrice Compositori, Bologna, 2010, pp. 90-93 
BOURDIN A., "Gentrification: un «concept» à déconstruire", in Espaces et sociétés, vol. 132-133, n.1, 2008, pp. 23-37

CALLARI GALLI M., "Il 'centro' è periferia", in Evangelisti F., Orlandi P., Piccinini M. (eds), La città storica contemporanea, Edisai, Ferrara, 2008, pp. 26-31

CAPUCCI M., "Sulla rigenerazione urbana: riflessioni a partire dalla esperienza del Villaggio Artigiano di Modena", in Inforum, 47, 2014, pp. 33-36

CASTELLS M., "European Cities, the Informational Society, and the Global Economy", in Journal of Economic and Social Geography, vol. 84, issue 4, 1993, pp. 247-257

CLERVAL A., COLOMB C., VAN CRIEKINGEN M., "La gentrification des métropoles européennes", in Pumain D., Mattei M., Données urbaines, Economica Anthropos, 6, 2011, pp.151-165

CORNEO D., "Viaggio nella Bolognina che cambia", in Corriere di Bologna, 01/04/2013

CRISTALDI F., Immigrazione e territorio. Lo spazio con/diviso, Bologna, Patron, 2013

FRÉMONT A., Vi piace la geografia?, (ed. it. a c. di Gavinelli D.), Roma, Carocci, 2007

GIUSBERTI C., "Officine Minganti al tramonto così è fallito il sogno commerciale nell'ex fabbrica della Bolognina”, in Repubblica, 21/08/2013

GOLDONI M. (eds), I quartieri e il decentramento. Bologna 1956-1975, Bologna, Fondazione Cassa di Risparmio di Bologna, 2004

KOTKIN J., The City: A Global History, The Modern Library, New York, 2005

LALLI P., "Volti migranti: nuove persone n città. Un laboratorio, una mostra, qualche fotografia", in A.A.V.V., Agenti metropolitani. Progetti per Bologna, Editrice Compositori, Bologna, 2010, pp. 94 -97

MARRA C., Musulmani e consumo halal: il caso delle macellerie islamiche in un quartiere di Bologna, Facoltà di Scienze Politiche, Alma Mater Studiorum - Università di Bologna, a.a. 2012/2013

PIANO b, "La fabbrica e il Dragone. Inchiesta sociale sulla Bolognina", in Metronomie, anno XIV GiugnoDicembre 2007

PISTOCCHI F., "Migrare humanum est... Migrazioni e insediamenti, lo sguardo della geografia", in Prandoni M., Salsi S. (eds), Minatori di memorie. Memoria culturale e culture della memoria nelle miniere e della migrazione italiana in Limburgo (belga e olandase) e Vallonia, Bologna, Pàtron, 2017, pp. 79-92

RUOCCO F., "Popolazioni, economie e spazi urbani a Bologna: continuità e mutamenti", in Marchi M., Penzo P., Tonini C. (eds), Città europee del XXI secolo. Luoghi e tempi del mutamento urbano, Bologna, Clueb, 2012, pp. 183-203
SASSEN S., "The Impact of the New Technologies and Globalization on Cities", in Graafland A., Hauptmann D. (eds), Cities in Transition, 010 Publishers, Rotterdam, 2001, pp. 327-348

SASSEN S., Le città nell'economia globale, Bologna, Il Mulino, 2008

SCANDURRA G, "Che tipo di periferie sono quelle bolognesi? Il caso della Bolognina", in A.A.V.V., Agenti metropolitani. Progetti per Bologna, Editrice Compositori, Bologna, 2010, pp. 86-89

SCANDURRA G., "Chi è il "vero bolognese"? La Bolognina e le sue molteplici cittadinanze", in A. Agustoni, A. Alietti (eds), Territori e pratiche di convivenza interetnica, Franco Angeli, Milano, 2015, pp. 113-140

SCROFANI L., RUGGIERO L. (eds), Temi di geografia economica, Torino, Giapichelli Editore, 2012

SEMI G., Gentrification. Tutte le città come Disneyland?, Bologna, Il Mulino, 2015

SOJA E. W., Dopo la metropoli. Per una critica della geografia urbana e regionale, Bologna, Pàtron, 2007

SPADEA M., "Etnografia di un mercato storico. Il mercato di via Francesco Albani, Bolognina, Bologna", pdf online

TANCREDI L., "Si chiude. Le fabbriche dismesse, nuovi vuoti di socialità", in Piazza Grande, anno 11, n. 10, 2005

TUAN, Y.-F., Space and Place: The Perspective of Experience, Minneapolis, University of Minnesota Press, 1977, p. 184

WHEELER S., Planning for sustainability. Creating livable, equitable, and ecological communities, London, Routledge, 2004

\section{WEB SITES (last access 30th April 2019)}

http://statistica.comune.bologna.it/quartieri/cittad inanza

http://inumeridibolognametropolitana.it/datistatistici/popolazione-residente-stranieraquartiere-zona-e-cittadinanza-dati-mensili

http://homepages.ulb.ac.be/ mvancrie/ulb/public ations_files/DU6\%20La\%20gentrification\%20cor r.pdf

https://ricerca.repubblica.it/repubblica/archivio/r epubblica/2013/08/21/officine-minganti-altramonto-cosi-fallito-il.html

http://www.comune.bologna.it/news/mercatoalbani-la-bolognina-che-cammina 